\title{
ANESTEZIJOS IR INTENSYVIOSIOS TERAPIJOS IŠPLĖSTINĖS PRAKTIKOS SLAUGYTOJAS ŪMINĖS PRIEŽIŪROS KOMANDOJE
}

\author{
Dovilè Stravinskaitė ${ }^{1}$, Lina Gedrimé $\dot{1}^{1}$, Jelena Kutkauskienė $\dot{2}^{2}$, Natalja Fatkulina ${ }^{1}$ \\ 'Vilniaus universiteto Medicinos fakulteto Sveikatos moksly institutas, \\ ${ }^{2}$ Mykolo Romerio Teisès mokyklos Viešosios teisès institutas
}

\begin{abstract}
Raktažodžiai: išplėstinès praktikos anestezijos intensyviosios terapijos slaugytojas, komandinis darbas, integracijos sunkumai, komandos narių požiūris.
\end{abstract}

\section{Santrauka}

Slaugytojai, studijuodami išplèstinès praktikos slaugą, susiduria su profesine resocializacija, o profesijos naujumas kelia didelius iššūkius ir reikalauja nuolatinio tobulinimo naujo vaidmens kūrimo, igyvendinimo ir vertinimo procese. Prieš integruojant išplèstinès praktikos anestezijos intensyviosios terapijos slaugytojo (IPAITS) vaidmenị i komandinį darbą, svarbu paruošti stiprius klinikinius specialistus, kurie turètų gilesnių žinių, aiškiai žinotų savo teises, pareigas, kompetenciją ir atsakomybę, gebėtų dirbti dinamiškoje aplinkoje bei turètų tvirtą klinicisto požiūrį. Tikslas - atliekant sisteminę literatūros analizę, apžvelgti išplèstinès praktikos anestezijos intensyviosios terapijos slaugytojo integravimą ị ūminès priežiūros komandas.

Tyrimo medžiaga ir metodai. Mokslinių straipsnių paieška vyko Medline, Google Scholar duomenų bazėse ir eLABa bei Cochrane talpyklose, naudojantis Vilniaus universiteto prieiga. Analizuojami straipsniai buvo skirstomi ị tris pogrupius pagal išsikeltus uždavinius. 1. Reanimacijos intensyviosios terapijos skyriuje (RITS) IPAITS komandos darbą papildo teikdamas ị pacientą orientuotą, mokslu grịstą medicininę priežiūrą pacientams, taip užtikrindamas geresnę sveikatos priežiūros kokybę ir sumažindamas darbo krūvị kitiems komandos nariams. Operacinèse (OP) IPAITS gali padidinti darbo našumą, dirbdamas savarankiškai pagal gydytojo anesteziologo reanimatologo sudarytą anestezijos planą, gydytojui prižiūrint. 2. Veiksniai, trukdantys sklandžiai integruoti IPAITS ị RITS ir OP komandas. 3. Išplèstinès praktikos anestezijos ir intensyviosios terapijos slaugytojo bendradarbiavimo galimybès.
Rezultatai. IPAITS vaidmuo RITS ir OP komandose formuojasi atsižvelgiant ị kvalifikacinius komandos narių laipsnius, vidaus dokumentuose aprašytas pareigybes ir funkcijas bei komandos susitarimus. Siekiant sèkmingai integruoti IPAITS specialistą, pagrindinès problemos kyla dèl profesinio pasitikẻjimo trūkumo, prasto IPAITS vaidmens išgryninimo, skirtingų išsilavinimo reikalavimų bei slaugytojų nomenklatūros skirtumų tarptautiniu mastu. Pastebèta, kad tarpprofesinio bendradarbiavimo galimybės yra palankesnès esant pozityviam komandos narių požiūriui.

\section{Ivadas}

Išplèstinès praktikos anestezijos ir intensyviosios terapijos slaugytojo darbas komandoje nèra plačiai išnagrinètas slaugos mokslininkų. Lietuvoje dar nebuvo atlikta tyrimų, kuriuose norima ištirti IPAITS darbą komandoje, nes šios kvalifikacijos slaugytojai dar neseniai ịteisinti Lietuvos sveikatos priežiūroje. Politinis pagrindas išplèstinès praktikos slaugytojo veiklai buvo 2017 metais liepos 7 dieną išleista Lietuvos medicinos norma 160:2017 „Išplèstinès praktikos slaugytojas" (MN). Šioje MN apibrēžta išplèstinès praktikos slaugytojo (IPS) kompetencija, pareigos ir atsakomybe [1]. Remiantis Lietuvos valstybinès akreditavimo sveikatos priežiūros veiklai tarnybos (VASPVT) duomenimis, 2021 metų vasario 25 dieną šalyje buvo užregistruoti trisdešimt penki IPS, iš kurių praktikuojasi trisdešimt keturi [2]. VASPVT nenurodo, kokios IPS specializacijos yra šie specialistai, nes MN 160:2017 apibrèžia, kad IPS dar skirstomi ị anestezijos ir intensyviosios terapijos, skubiosios medicinos pagalbos ir pirminès sveikatos priežiūros specializacijas [1,2]. Tai parodo, kad IPAITS skaičius Lietuvoje yra labai nedidelis ir ši specialybè dar tik pradeda įsitvirtinti sveikatos priežiūros komandose.

Norint palengvinti IPAITS integravimą į tarpprofesines komandas, svarbu numatyti galimas kliūtis ir iššūkius. 
Viename Didžiosios Britanijos tyrime buvo nustatyta, kad slaugytojai, dirbantys ūminès sveikatos priežiūros srityje, mato tris pagrindines kliūtis, trukdančias dirbti tarpprofesinëje komandoje - skirtingai suvokiamas komandinis darbas, skirtingas komandos narių išsilavinimas ir medicininès (hierarchinès) galios dominavimas, kuris ypač riboja komunikavimą komandoje [3]. Kitas tyrimas, kuriame pateikiama IPS vaidmens Kanadoje kūrimo ir igyvendinimo sisteminè apžvalga, papildo ūmios priežiūros slaugytojų nuomonę ir nurodo, kad komandos narių noras bendradarbiauti yra vienas iš pagrindinių veiksnių, lengvinantis IPS integravimo procesą [4]. Sisteminès literatūros apžvalgos apie IPS ir sveikatos priežiūros komandinį darbą analizè parodè, kad palaikymas yra svarbus tiek tarpprofesinejje, tiek ir tarpdisciplininejje komandoje. Vienas iš dažniausių IPS integracijos iššūkių yra skirtingas IPS vaidmens suvokimas, todèl ịžvelgiama, kad realizuojant IPS vaidmenį komandiniame darbe, svarbus vadovų dalyvavimas [5].

Nepaisant iššūkių, kitų šalių pavyzdžiai rodo, kad sèkmingas IPS vaidmenų nustatymas komandose gali padèti efektyviau naudoti išteklius ir pagerinti sveikatos priežiūros paslaugų teikimą. Išplèstinès praktikos slauga bėgant metams vystèsi ir tapo pripažinta kaip svarbi ir auganti tendencija sveikatos priežiūros sistemose visame pasaulyje [6,7].

Tyrimo tikslas - atliekant sisteminę literatūros analizę, apžvelgti išplèstinès praktikos anestezijos intensyviosios te-

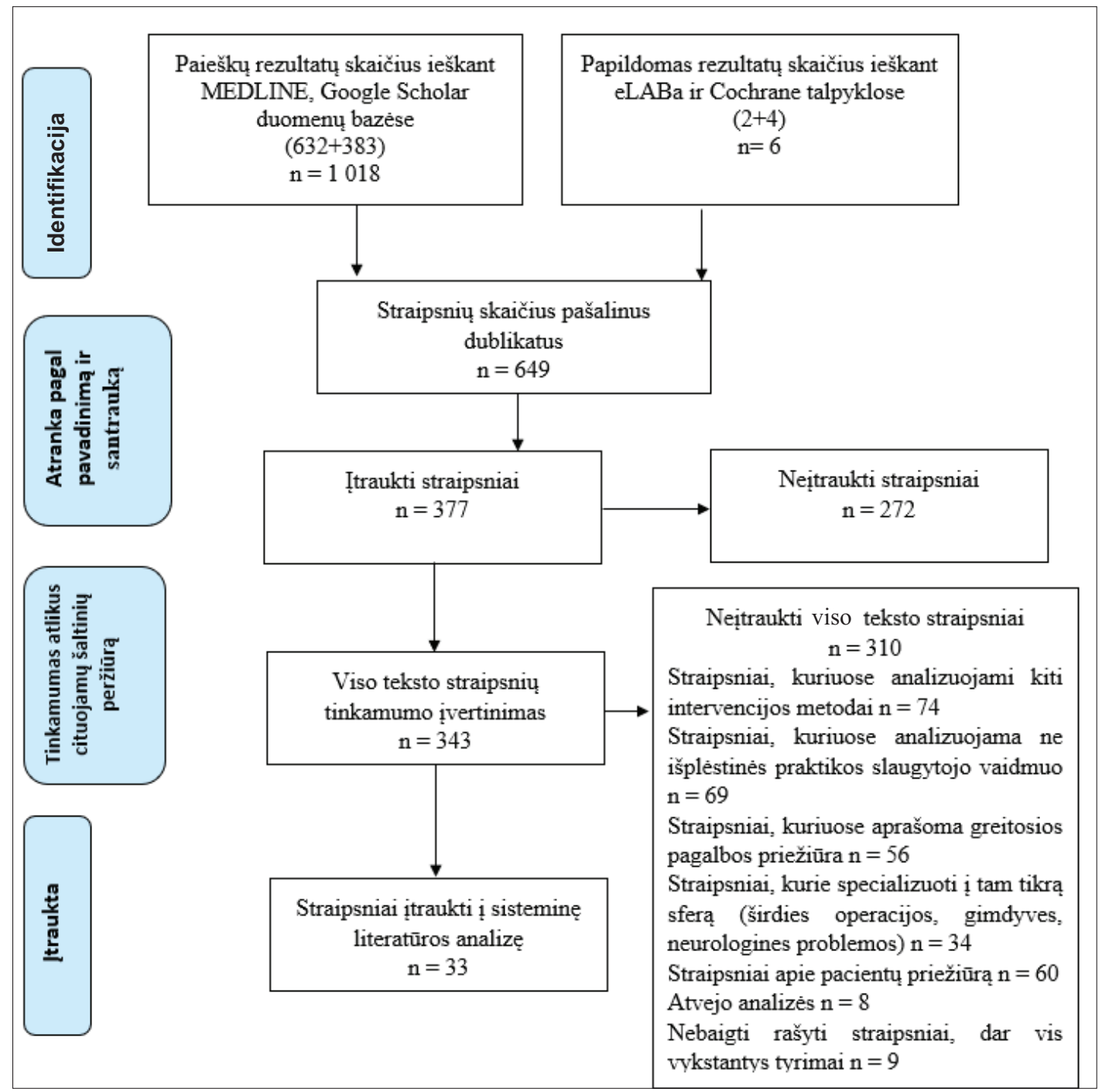

1 pav. Mokslinių straipsnių atrankos procesas

Pagal Moher D, Liberati A, Tetzlaff J, Altman DG, PRISMA grupès sistemingos literatūros apžvalgos atrankos šablona [8]. 
rapijos slaugytojo integravimą ị ūminès priežiūros komandas.

Tyrimo uždaviniai: 1) aprašyti išplèstinès praktikos anestezijos intensyviosios terapijos slaugytojo vaidmenis, dirbant reanimacijos intensyvios terapijos skyriuje ir operacineje; 2)identifikuoti ir aprašyti veiksnius, trukdančius sklandžiai integruoti išplèstinès praktikos slaugytoją ị ūminès priežiūros komandas; 3) apžvelgti išplèstinès praktikos anestezijos ir intensyviosios terapijos slaugytojo profesinès socializacijos ir bendradarbiavimo galimybes tarpprofesinèje komandoje.

\section{Tyrimo medžiaga ir metodai}

Siekiant giliau išnagrinèti išsikeltus darbo uždavinius, 2020 metų liepos-lapkričio mẻnesiais buvo atlikta literatūros sisteminė apžvalga. Mokslinių straipsnių paieškos užklausoje buvo naudojami temą atitinkantys raktažodžiai ir jų deriniai. advanced practice nursing (APN), APN integration in intensive care unit (ICU) team, APN integration in operating room (OR) team, APN competency, APN roles, APN professional confidence, nurse anaesthesia interprofessional team work, interprofessional collaboration, interprofessional team attitude. Raktažodžiai jungti tarpusavyje or ir and junginiais, vietoje APN taip pat buvo naudojami užsienyje sutinkami atitikmenys clinical nurse specialists, nurse practitioner, nurse specialists. Dublikatams pašalinti ir literatūros sąrašui kurti naudota „Mendeley Web Importer“ ir „Mendeley Desktop“ programos. Mokslinių straipsnių paieškos ir atrankos procesas parodytas 1 paveiksle.

Straipsnių atrankos kriterijai: 1) straipsnis publikuotas patikimame moksliniame žurnale; 2) viso teksto mokslinis straipsnis anglų, lietuvių kalbomis; 3) straipsnis išleistas ne seniau nei prieš 5 metus, išimtys taikytos, jei pagal užklausą buvo nerasta norimos informacijos.

Literatūros analizavimo turinys buvo struktūruotas ị 3 skyrius. Kiekviename skyriuje buvo analizuojami išsikelti uždaviniai.

\section{Rezultatai ir jų aptarimas}

Išplèstinès praktikos anestezijos ir intensyviosios terapijos slaugytojo vaidmuo reanimacijos intensyviosios terapijos skyriuje ir operacinèje

Reanimacijos intensyviosios terapijos skyrius. Pagrindinę RITS komandą sudaro gydytojas anesteziologas-reanimatologas (GAR), anestezijos ir intensyviosios terapijos slaugytojai (AITS), išplèstinès praktikos anestezijos ir intensyvios terapijos slaugytojai ir slaugytoju padejejjai. Esant individualiu paciento poreikių, dažnai ittraukiami gydytojai chirurgai bei neurologai, kvėpavimo terapijos specialistai, kineziterapeutai, vaistininkai, mikrobiologai, socialiniai darbuotojai, etikai, dvasinès priežiūros terapeutai ir daugelis kitų specialistų. Visame gydymo procese svarbus paciento artimųų vaidmuo [9].

Išplèstinès praktikos anestezijos ir intensyviosios terapijos slaugytojų nèra visose RITS komandose, tačiau yra šaliu, pavyzdžiui Jungtinès Amerikos Valstijos (JAV), kur išplèstinès praktikos anestezijos specialistai įsitvirtinę RITS komandose ir turi pabaigti ne tik magistrantūros, bet ir doktorantūros studijas $[10,11]$. Šie specialistai atlieka trachejos intubaciją, endotrachẻjinio vamzdelio keitimą, reguliuoja dirbtinès plaučių apykaitos aparatą, stebi paciento hemodinamiką ir punktuoja arterijas bei centrines venas. Slaugytojai praktikai turi gilesnių farmakologijos, fiziologijos, patofiziologijos ir pacientų priežiūros žinių, nei anestezijos ir intensyviosios terapijos slaugytojai [12]. Lyginant IPAITS tarptautiniu mastu, matomas labai didelis skirtumas, priklausomai nuo valstybès įsakymų, švietimo reikalavimų, reglamentavimo ir praktikos taikymo sričių $[13,14]$.

Rasta nemažai straipsnių, nagrinėjančių IPS vaidmenis, dirbant ūminès ir kritinès priežiūros sąlygomis. Viename tyrime buvo apžvelgta 145 straipsnių santrauka, kuri apibrěžè tokius specialistų vaidmenis:

1. Paciento priežiūros valdymas: paciento priežiūra viso gydymo metu, ligos istorijos pildymas, tyrimų užsakymas ir vertinimas, pagal protokolą inicijuojamas personalo darbas, procedūrų pagal kompetenciją atlikimas.

2. Edukacinès veiklos personalui, pacientams ir jų šeimoms vykdymas.

3. Medicininių gairių igyvendinimo praktikavimas.

4. Darbo kokybės užtikrinimas: vadovauti kokybės užtikrinimui, pvz., siekti sumažinti su dirbtine plaučių apykaita susijusią pneumoniją, gerinti septinio šoko valdymą, tobulinti greito reagavimo komandas.

5. Mokslinè tiriamoji veikla: duomenų rinkimas, tiriamųjų registracija, mokslinių tyrimų valdymas.

6. Komunikacija: skatinti ir stiprinti bendravimą su RITS kolektyvu, paciento šeimos nariais, tarpdisciplininès komandos nariais.

7. Rekomendacijų teikimas [15].

Išplèstinės praktikos slaugytojas turi prisidèti prie pacientų priežiūros, integruojant išsamias slaugos žinias ir patirtị, susijusią su klinikine praktika, švietimu, moksliniais tyrimais, profesiniu tobulinimu ir lyderyste $[6,16]$. Tokių specialistų nèra visose RITS komandose, nors tyrimai rodo, kad išplèstinès praktikos slaugos specialisto buvimas yra susijęs su aukštesniais paciento saugos balais, gebejjimu gerinti komandos aplinką, spręsti paciento ar personalo problemas, komunikacijos nesklandumus ir, svarbiausia, numatyti ar užkirsti kelią paciento būklès pablogejjimui [17].

Operacinè. Operacinès komandą sudaro labai specializuoti, skirtingas funkcijas atliekantys nariai: chirurgijos, anestezijos ir operacinès priežiūros specialistai. Nors kie- 
kvienas atlieka skirtingą vaidmenį, visi kartu siekia bendro tikslo - kuo labiau pagerinti paciento sveikatą. Tarpusavio bendradarbiavimas tarp komandos narių yra glaudžiai susijęs ir priklauso nuo esamos situacijos - daugiausia nuo operacijos tipo ir eigos. Bendradarbiauti tenka esant gyvybei pavojingoms situacijoms, todèl komandos nariai privalo derinti klinikines žinias su praktiniais ịgūdžiais. Dẻl skirtingu vaidmenų ir bendro tikslo, komandos nariai yra priklausomi vienas nuo kito, todèl dažniausiai operacinès komandose susidaro skirtingos socialinès struktūros, o specialistų vaidmenis formuoja aiškios gairès ir numanomos normos, kurios nusako specialistų padètị komandoje - kas užima vadovo vaidmeni, o kas paklūsta [18-20].

Anestezijos specialistu vaidmenys. Bus aptariamas dviejų specialistų vaidmuo, atliekant anesteziją: GAR ir sertifikuoto registruoto slaugytojo anesteziologo (SRSA), kurio apibrèžimas dažniausia atitinka IPAITS. Šių specialistų vaidmenys, užduočių pasiskirstymas ir net komandos sudètis skiriasi priklausomai nuo valstybès ir joje reglamentuoto šių specialistų rengimo, kompetencijos, pareigų ir atsakomybès [21,22]. Nagrinejjant Prancūzijos pavyzdị matoma, kad teisès aktuose yra griežtai apibrèžiama, kad GAR turi būti fiziškai pasiekiamas operacijos metu, o SRSA gali dirbti tik pagal raštu pateiktą anestezijos strategiją, kurioje nurodytas anestezijos metodas, tikslai bei pasirinkimo ir įgyvendinimo galimybès. Teisès aktuose taip pat apibrezžiama, kad visais anestezijos etapais SRSA turètų sugebèti pastebèti ir nustatyti komplikacijas ar fiziologinius paciento sveikatos būklès pablogèjimus ir apie pakitimus nedelsiant informuoti GAR. Jei paciento būkle stabili, o operacijos eiga sklandi, o GAR įvertina, kad jo dalyvavimas nèra būtinas, SRSA gali savarankiškai prižiūrèti pacientą, bet tik su sąlyga, kad anesteziologas yra lengvai pasiekiamas bet kuriuo metu. SRSA turi teisę atlikti procedūras, kurios priklauso jų kvalifikacijai: pradèti taikyti bendrą anesteziją pagal sudarytą anestezijos protokolą, bet negali pakeisti ar pavaduoti anesteziologo, visada turi dirbti prižiūrimas gydytojo, kad esant nenumatytai situacijai, gydytojas galètų nedelsiant ịsikišti. Prancūzijoje populiarus darbo modelis, kai dviejose operacinèse dirba du SRSA ir vienas GAR [23]. Prancūzijos anestezijos specialistų bendradarbiavimo sistemoje labai svarbu tinkamas anestezijos specialistų komandinio darbo koordinavimas.

Anestezijos specialistai, žinodami operacijos planą, pasirenka anestezijos metodą ir medikamentus. Priklausomai nuo paciento būklès, papildomi medikamentai gali būti skiriami tiek operacijos metu, tiek po jos pagrindinių organų sistemos funkcijai palaikyti [24]. Anesteziologai skiria profilaktinę antibiotikų terapiją tam, kad būtų išvengta pooperacinių infekcijų, valdo ir užtikrina paciento kvèpavimo ir hemodinamikos stabilumą [25]. Pasaulinè sveikatos organizacija
(PSO) pažymi, kad anestezijos specialistų svarbiausias vaidmuo yra laikantis visų anestezijos priežiūros reikalavimų ir bendradarbiaujant su chirurgais užtikrinti pacientų saugumą tiek operacijos metu, tiek po jos [26].

Veiksniai, trukdantys sklandžiai integruoti išplèstinès praktikos slaugytoją i tarpprofesinę komandą. Ivairios pasaulio šalys ịvardija ne vieną problemą, trukdančią sklandžiai integruoti išplèstinès kompetencijos slaugytojus ị komandini darbą [27].

- Skirtinga IPS slaugytojų nomenklatūra. Vienu metu ivvairiose šalyse besivystanti ir plečianti skirtingų sričių kompetencijas IPS igavo skirtingus pavadinimus, kurie gali sukelti painiavą nagrinejjant literatūrą tarptautiniu mastu. Klinikinis slaugos specialistas (angl. clinical nurse specialists) dažnai sutinkamas apibūdinimas Airijoje, Australijoje, Graikijoje, Irane, JAV, Italijoje, Kanadoje, Lenkijoje. Slaugytojas praktikas (angl. nurse practitioner) gali būti sutinkamas Jungtinejje Karalysteje, Italijoje, Graikijoje, Nyderlanduose, Portugalijoje, IPS (angl. advanced practice nurse) apibrèžtis naudojama Airijoje, Australijoje, Ispanijoje, Lietuvoje, Suomijoje ir kitur. Rečiau sutinkamas apibūdinamas slaugos specialistas (angl. nurse specialists) - Tailande, Irane, Botsvanoje [7,28].

- Profesinio pasitikèjimo trūkumas. Išplèstinès praktikos anestezijos ir intensyviosios terapijos slaugytojų magistrantūros studijomis siekiama išplèsti ir ịtvirtinti pažangias klinikines teorijas ir igūdžius. R. Baxter ir D. Edvardsson straipsnyje teigiama, kad kritinès priežiūros magistrantūros baigimas žymiai padidino slaugytojų suvokiamą kompetenciją ir pasitikejimą savimi [29]. B. Jackson ir bendraautorių apžvalgoje nurodama, kad patyrę specialistai yra vieni iš pagrindinių mentorių, nuolatos padedančiu plèsti sveikatos priežiūros darbuotojų profesinį tobulèjimą, bet specialistai ne visada noriai priima paskirtą mentoriaus vaidmenį. Atsiranda vaidmenų neaiškumas, profesinio statuso nužeminimas ir skatinamas vaidmenų konfliktas, keliantis grèsmę naujai praktikuojančio specialisto pasitikejjimui [30]. K. Pfaff ir bendraautoriai pažymi, kad bendradarbiavimas ir paramos teikimas tobulinant ir ịsisavinant naujus ịgūdžius yra būtinas, norint sustiprinti naujų slaugytojų pasitikejjimą tarpprofesiniu bendradarbiavimu [31].

- Prastas vaidmens išgryninimas. I susiformavusią komandą integruojant išplèstinès kompetencijos slaugytoją tenka perskirstyti darbo krūvị tarp komandos narių. Kyla problemų, kai slaugytojo, gydytojo ir kitų sveikatos priežiūros specialistų kompetencijos persipina [32]. Atliekamų vaidmenų aiškumas leidžia įgauti pripažinimą ir didina tarpusavio pasitikèjimą, duodantị geresnius darbo rezultatus [33].

- Skirtingi išsilavinimo reikalavimai [27]. Tarptautinè slaugytojų taryba rekomendaciniame dokumente apibrè- 
žia įvairius elementus, leidžiančius formuotis išplèstinès praktikos slaugytojo vaidmens sveikatos priežiūroje viziją. Rekomendacinėse praktikos gairèse akcentuojama, kad IPS yra reikalingas oficialus švietimas, minimalus reikalaujamas lygmuo - magistro laipsnis [34].

Išplèstinès praktikos anestezijos ir intensyviosios terapijos slaugytojo bendradarbiavimo galimybès. Siekiant sèkmingos profesinès integracijos, svarbų vaidmeni atlieka tarpprofesinis bendradarbiavimas. Daug ịtakos turi ir kitu sveikatos priežiūros specialistų požiūris ị slaugytojo vaidmens plètrą. Pozityvus ar negatyvus požiūris lemia lengvesnę arba sunkesnę IPS adaptaciją sveikatos priežiūros sistemoje [35]. Gydytojai ir slaugytojai glaudžiausiai bendradarbiauja dirbdami komandoje, todèl nuo jų požiūrio priklauso, ar išplèstinès praktikos slaugytojas bus sutiktas noriai ir lengvai integruosis į tarpprofesinę komandą. Izraelyje atliktas kiekybinis tyrimas parode, kad tiek slaugytojai, tiek gydytojai sutiko, kad praplèstas slaugytojo vaidmuo didina pacientu pasitikèjimą, gerina veiklos ekonomiškumą. Slaugytojai ir gydytojai sutiko, kad IPS galètų atlikti paciento vertinimą ir surinkti ligos anamnezę, paskirti vaistus ir gydymą pagal standartinius protokolus, paskirti ir interpretuoti laboratorinius ir diagnostinius tyrimus. Tyrime buvo nustatyta, kad kuo didesnis gydytojo darbo stažas, tuo pesimistiškiau vertinami galimi pokyčiai. Tiriant slaugytojų nuomonę pastebėta, kad turintys akademinius laipsnius ir aukštesnes pareigas užimantys slaugytojai išreiškia palankesnị požiūrị i I IPS. Tyrimas parodè, kad daugiau nei $2 / 3$ tiriamujų labiau pritaria IPS integracijai, nei nepritaria. Interpretuojant tyrimo duomenis manoma, kad slaugytojai labiau pritaria slaugos vaidmens išplètimui nei gydytojai, nors apskritai gydytojai palaiko slaugytojų praktikos išplètimą [36]. Airijoje atliktas tyrimas parode, kad kyla problemų apibrèžiant IPS vaidmenis, nes tik 11 proc. tyrimo dalyvių nurodè, kad aiškiai suprato IPS vaidmenį. Tyrimo rezultatai parodè, kad požiūris į IPS vaidmenį yra sudètingas ir daugialypis. Ir Izraelyje, ir Airijoje atliktuose tyrimuose buvo nustatyta, kad slaugytojai labiau pritaria IPS integracijai, nei gydytojai, tačiau iš esmès vieni ir kiti specialistai šiam pokyčiui labiau pritaria nei nepritaria [37].

Lietuvoje problema panaši. Viename iš naujausių tyrimų teigiama, kad iš 131 gydytojo anesteziologo-reanimatologo 92 proc. respondentų nurodè, jog jiems trūksta žinių apie IPS profesiją [38], tačiau Lietuvoje ženkli anestezijos ir intensyvios terapijos slaugytojų branda, tobulejjimas ir pasirengimas naujai veiklai. Naujausias tyrimas rodo, kad dauguma Lietuvos anestezijos intensyviosios terapijos slaugytojų jau atlieka kai kurias išplèstinès praktikos funkcijas: stebi pacientu skysčių balansą, pagal kintamą hemodinamiką taiko infuzijos terapijos kontrolę, taiko klinikinès farmakologijos žinias teikiant anesteziją, gaivinant, intensyviai gydant pacientus [39].

\section{Išvados}

1. Reanimacijos-intensyviosios terapijos skyriuje IPAITS komandos darbą papildo teikdamas ị pacientą orientuotą, mokslu grịstą medicininę priežiūrą, taip užtikrindamas geresnę pacientų sveikatos priežiūros kokybę ir palengvindamas darbo krūvị komandos nariams. Operacinèse IPAITS gali padidinti darbo našumą ir, prižiūrimas gydytojo anesteziologo reanimatologo, dirbti savarankiškai pagal gydytojo anesteziologo reanimatologo sudarytą planą.

2. Siekiant sėkmingai integruoti IPS specialistą, problemų kyla dèl profesinio pasitikejimo trūkumo, prasto IPS vaidmens išgryninimo, skirtingų išsilavinimo reikalavimų bei slaugytojų nomenklatūros skirtumų.

3. Pastebeta, kad tarpprofesinio bendradarbiavimo galimybès palankesnès, esant pozityviam komandos narių požiūriui.

\section{Literatūra}

1. LR sveikatos apsaugos ministro $2017 \mathrm{~m}$. liepos $7 \mathrm{~d}$. ịsakymas Nr.V-852 Dèl Lietuvos medicinos normos MN 160:2017 „Išplèstinès praktikos slaugytojas“" patvirtinimo. TAR, 201707-12, Nr.12017

https://e-seimas.lrs.lt/portal/legalAct/lt/TAD/96b1d63166cf11 e7a53b83ca0142260e?jfwid=11 dyheoksi

2. Valstybinè akreditavimo sveikatos priežiūros veiklai tarnyba prie Sveikatos apsaugos ministerijos. SPS licencijų sąrašas. https:// licencijavimas.vaspvt.gov.lt/License/PublicSpecialistIndex

3. Atwal A, Caldwell K. Nurses' perceptions of multidisciplinary team work in acute health-care. Int J Nurs Pract. 2006;12(6):359-65.

https://doi.org/10.1111/j.1440-172X.2006.00595.x

4. Di Censo A. Clinical nurse specialists and nurse practitioners in Canada: a decision support synthesis. 2010.

5. Kilpatrick K, Ritchie JA, Lamothe L. Advanced practice nursing, health care teams, and perceptions of team effectiveness 2011;30(3):215-26.

https://doi.org/10.1097/HCM.0b013e318225e03a

6. Delamaire M, Lafortune G. Nurses in advanced roles: a description and evaluation of experiences in 12 developed countries. OECD Heal Work Pap 2010;(54).

7. Sheer B, Kam F, Wong Y. The Development of advanced nursing practice globally. J Nurs Scholarsh 2008;40(3):2004-211.

https://doi.org/10.1111/j.1547-5069.2008.00242.x

8. Moher D, Liberati A, Tetzlaff J, Altman G, Altman D, Antes $\mathrm{G}$, et al. Preferred reporting items for systematic reviews and meta-analyses: the PRISMA statement. PLoS Med 2009;6(7):e1000097.

https://doi.org/10.1371/journal.pmed.1000097

9. Marshall JC, Bosco L, Adhikari NK, Connolly B, Diaz J V., Dorman T, et al. What is an intensive care unit? A report of the task force of the World Federation of Societies of Intensive and 
Critical Care Medicine. J Crit Care 2017;37:270-6.

https://doi.org/10.1016/j.jcrc.2016.07.015

10. Ray WT, Desai SP. The history of the nurse anesthesia profession. J Clin Anesth. 2016;30:51-8.

https://doi.org/10.1016/j.jclinane.2015.11.005

11. Madsen R, Walker J, Horton B, Martin-Sheridan D, Yablonky M, Gerbasi F. Council on accreditation of nurse anesthesia educational programs. AANA J 2014;82(3):177-83.

12. Kleinpell RM, Hravnak M, Werner KE, Guzman A. Skills taught in acute care np programs: a national survey. Nurse Pract 2006;31(2). https://doi.org/10.1097/00006205-200602000-00003

13. Heale R, Rieck Buckley C. An international perspective of advanced practice nursing regulation. Int Nurs Rev 2015;62(3):421-9.

https://doi.org/10.1111/inr.12193

14. Parker JM, Hill MN. A review of advanced practice nursing in the United States, Canada, Australia and Hong Kong Special Administrative Region (SAR), China. International Journal of Nursing Sciences 2017;4:196-204.

https://doi.org/10.1016/j.ijnss.2017.01.002

15. Kleinpell RM, Ely EW, Grabenkort R. Nurse practitioners and physician assistants in the intensive care unit: an evidencebased review. Crit Care Med 2008;36(10):2888-97.

https://doi.org/10.1097/CCM.0b013e318186ba8c

16. Bryant-Lukosius D, DiCenso A. A framework for the introduction and evaluation of advanced practice nursing roles. J Adv Nurs 2004;48(5):530-40.

https://doi.org/10.1111/j.1365-2648.2004.03235.x

17. Robinson J, Clark S, Greer D. Neurocritical care clinicians' perceptions of nurse practitioners and physician assistants in the intensive care unit. J Neurosci Nurs 2014;46(2):E3-7. https://doi.org/10.1097/JNN.0000000000000040

18. Lingard L, Reznick R, Espin S, Regehr G, DeVito I. Team communications in the operating room: talk patterns, sites of tension, and implications for novices. Acad Med 2002;77(3):232-7. https://doi.org/10.1097/00001888-200203000-00013

19. Gfrörer R, Schüpfer G, Schmidt CE, Bauer M. Teambildung im operationssaal. Auswirkungen auf die entscheidungsqualität. Anaesthesist 2005;54(12):1229-34.

https://doi.org/10.1007/s00101-005-0932-0

20. Yule S, Flin R, Paterson-Brown S, Maran N. Non-technical skills for surgeons in the operating room: a review of the literature. Surgery 2006;139(2):140-9.

https://doi.org/10.1016/j.surg.2005.06.017

21. Sheer B, Wong F. The development of advanced nursing practice globally. J Nurs Scholarsh 2008;40(3):204-11. https://doi.org/10.1111/j.1547-5069.2008.00242.x

22. Egger Halbeis CB, Schubert A. Staffing the operating room suite: perspectives from Europe and North America on the role of different anesthesia personnel. Anesthesiology Clinics.
Elsevier 2008;26:637-63.

https://doi.org/10.1016/j.anclin.2008.07.002

23. Fischler M, Cardin JL, Faucon T, Adam R. Presence of anesthesiologists and nurses in the operating room: liability of surgeons and health care facilities. Journal of Visceral Surgery 2019;156:S15-20.

https://doi.org/10.1016/j.jviscsurg.2019.05.008

24. White PF, Kehlet H, Neal JM, Schricker T, Carr DB, Carli F. The role of the anesthesiologist in fast-track surgery: from multimodal analgesia to perioperative medical care. Anesth Analg 2007;104(6):1380-96.

https://doi.org/10.1213/01.ane.0000263034.96885.e1

25. Wacker J, Staender S. The role of the anesthesiologist in perioperative patient safety. Current Opinion in Anaesthesiology 2014;27(6):649-56.

https://doi.org/10.1097/ACO.0000000000000124

26. Merry AF. Role of Anesthesiologists in WHO Safe Surgery Programs. Int Anesthesiol Clin. 2010;48(2):137-50.

https://doi.org/10.1097/AIA.0b013e3181cd1615

27. Kleinpell M. Addressing issues impacting advanced nursing practice worldwide. OJIN. 2014;19(2):1.

28. Woo B, Lee J, Tam W. The impact of the advanced practice nursing role on quality of care, clinical outcomes, patient satisfaction, and cost in the emergency and critical care settings: a systematic review. Human Resources for Health 2017;15(1):63. https://doi.org/10.1186/s12960-017-0237-9

29. Baxter R, Edvardsson D. Impact of a critical care postgraduate certificate course on nurses' self-reported competence and confidence: A quasi-experimental study. Nurse Educ Today 2018;65:156-61.

https://doi.org/10.1016/j.nedt.2018.03.004

30. Jackson BN, Purdy SC, Cooper-Thomas HD. Role of professional confidence in the development of expert allied health professionals: a narrative review. J Allied Health 2019;48(3):226-34.

31. Pfaff KA, Baxter PE, Jack SM, Ploeg J. Exploring new graduate nurse confidence in interprofessional collaboration: a mixed methods study. Int J Nurs Stud 2014;51(8):1142-52.

https://doi.org/10.1016/j.ijnurstu.2014.01.001

32. Hepp SL, Suter E, Jackson K, Deutschlander S, Makwarimba $\mathrm{E}$, Jennings $\mathrm{J}$, et al. Using an interprofessional competency framework to examine collaborative practice. J Interprof Care 2015;29(2):131-7.

https://doi.org/10.3109/13561820.2014.955910

33. Burgess J, Purkis M. The power and politics of collaboration in nurse practitioner role development. Nurs Inq 2010;17(4):297308.

https://doi.org/10.1111/j.1440-1800.2010.00505.x

34. Schober M, Lehwaldt D, Rogers M, Steinke M, Turale S, Pulcini $\mathrm{J}$, et al. Guidelines on advanced practice nursing. Switzerland: International Council of Nurse 2020.

35. Pullon S. Competence, respect and trust: key features of su- 
ccessful interprofessional nurse-doctor relationships. J Interprof Care 2008;22(2):133-47.

https://doi.org/10.1080/13561820701795069

36. Brodsky E, Van Dijk D. Advanced and specialist nursing practice: attitudes of nurses and physicians in Israel. J Nurs Scholarsh 2008;40(2):187-94. https://doi.org/10.1111/j.1547-5069.2008.00225.x

37. Griffin M, Melby V. Developing an advanced nurse practitioner service in emergency care: attitudes of nurses and doctors. J Adv Nurs 2006;56(3):292-301. https://doi.org/10.1111/j.1365-2648.2006.04025.x

38. Jasukaitienė E. Išplèstinès praktikos slaugytojų kompetencijų ir teisinès apsaugos vertinimas gydytojų anesteziologų-reanimatologų požiūriu. Kaunas: LSMU, 2017 https://www.lsmuni.lt/cris/handle/20.500.12512/101842

39. Rakauskaitė D. Išplèstinès slaugos praktikos plètros galimybių ìvertinimas anestezijos ir intensyviosios terapijos slaugytojų požiūriu. Kaunas: LSMU, 2020 https://193.219.163.160/cris/ handle/20.500.12512/108103

\section{ADVANCED PRACTICE ANESTHESIA AND INTENSE THERAPY NURSE IN A ACUTE CARE UNIT: SYSTEMATIC LITERATURE REVIEW}

\section{Stravinskaitė, L. Gedrimė, J. Kutkauskienė, N. Fatkulina}

Keywords: advanced practice anesthesia and intense care nurse, teamwork, the difficulties of integration, the view of team members.

Summary

Nurses, who study advanced practice nursing, experience career resocialization. The freshness of the profession raises new challenges and requires constant improvement, development and refinement for complete integration. Before full incorporation of an advanced practice anesthesia and intense care nurses (further on APAICN) into an organized team, it is important to prepare highly skilled specialists, who would not, just excel in their deeper knowledge and understanding of required rights, duties, competencies and responsibilities, but even be able to engage in a well thought out practice, work in a dynamic environment and have a strong clinician approach. Goal - review the integration of the advanced practice anesthesia and intensive care nurse into acute care teams through a systematic literature overview. Research material and methods - The search for scientific articles took place in MEDLINE, Google Scholar databases and eLABa and Cochrane repositories using Vilnius University access. The analyzed articles were divided into three subgroups according to the tasks set: 1 . In the intensive care unit (further on - ICU) the APAICN enrich the team by providing a patient oriented and science based medical care, thus ensuring better quality of health care and easing the workload for other team members. Meanwhile in the operating room (further -OR) the APAICN can increase work efficiency by working independently according to the anesthesia plan drawn up by the anesthesiologist and under his supervision. 2. Factors hindering the smooth integration of APAICN into ICU and OR teams. 3. APAICN professional socialization and opportunities for cooperation. Results. The role of APAICN in ICU and OR teams is formed on the basis of the qualification degrees of the team members, the positions and functions described in law and the internal agreements of the team. The main problems in successful integration of the APAICN specialist arise from lack of professional confidence, poor APAICN role development, different educational requirements and differences in nursing nomenclature internationally. It was observed that the opportunities for interprofessional cooperation are more favorable in teams with a positive attitude.

Correspondence to: dovilee134@gmail.com

Gauta 2021-03-09 